SILVA, H. J. O.; SOUZA, A. F. G. O.; GARCIA, E. R. M.; LEITE, M. C. P.; CASSUCI, L. G. T.; DOMINGUES, E. C. S.; MARQUES, A. L. R.; SANTOS, J. P. G.; COSTA, G. S.; MACHADO, D. C.; SILVA, M. V. Rearing density in the performance and profitability of ross 308 broilers. Revista de Agricultura Neotropical, Cassilândia-MS, v. 8, n. 2, e5856, abr./jun. 2021. ISSN 2358-6303. DOI: https://doi.org/10.32404/rean.v8i2.5856.

\title{
Rearing density in the performance and profitability of ross 308 broilers
}

\section{Higor Jonathan de Oliveira Silva ${ }^{1}$, Andréia Fróes Galuci Oliveira de Souza ${ }^{1}$, Elis Regina de Moraes Garcia ${ }^{2}$, Meiby Carneiro de Paula Leite ${ }^{3}$, Leticia Gabriela Talhaferro Cassuci ${ }^{1}$, Elyan Carlos da Silva Domingues ${ }^{1}$, Ana Letícia Ribeiro Marques ${ }^{1}$, João Paulo Gomes dos Santos ${ }^{1}$, Gabriela da Silva da Costa ${ }^{1}$, Dayane Camargo Machado ${ }^{1}$, Maria Vitória Silva ${ }^{1}$}

\footnotetext{
${ }^{1}$ Universidade Estadual de Mato Grosso do Sul, Unidade Universitária de Cassilândia, Cassilândia, Mato Grosso do Sul, Brasil. Email: higorjonathan12@gmail.com, galuci@uems.br, ermgarcia@uems.br, leticiacassuci@hotmail.com, elyan784@gmail.com, leticia_xis@hotmail.com, joao.paulogomes@outlook.com, gaaabilu001@outlook.com, dayabecamargo18@hotmail.com, vgel12628@gmail.com

${ }^{2}$ Universidade Estadual de Mato Grosso do Sul, Unidade Universitária de Aquidauana, Aquidauana, Mato Grosso do Sul, Brasil. E-mail: ermgarcia@uems.br

${ }^{3}$ Universidade Federal do Recôncavo da Bahia, Campus Cruz das Almas, Cruz das Almas, Bahia, Brasil. E-mail: meiby@ufrb.edu.br Received: 03/02/2021; Accepted: 16/03/2021.
}

\section{ABSTRACT}

The objective was to evaluate the effect of stocking density on productive performance, carcass characteristics, productivity, bone development, and profitability of Ross 308 broilers. A completely randomized experimental design with four stocking densities $\left(10,12,14\right.$, and 16 birds $\left.\mathrm{m}^{-2}\right)$ and four replicates, and the subplots the bone collection ages $(7,14,21,28,35$, and 42 days old). The variables analyzed were live weight at 21 and 42 days, weight gain, feed intake, and conversion in the accumulated periods from 1 to 21 and 1 to 42 days. Weights of carcasses, commercial cuts, edible viscera, abdominal fat, productivity, production efficiency index, viability, and profitability were evaluated. The length, thickness, weight, and Seedor index of long bones (tibiotarsus and femur) were also evaluated. The yield was higher for densities of 14 and 16 birds $\mathrm{m}^{-2}$. The thickness of the tibiotarsus was lower in the density of 12 birds $\mathrm{m}^{-2}$. The increase in the stocking density of 10 or 12 birds m${ }^{-2}$, to 14 birds $\mathrm{m}^{-2}$ allows greater productivity per area, without compromising the productive performance, such as carcass characteristics and the animal's bone development, besides being the breeding density with the highest profitability, considering the welfare of Ross 308 broilers.

Keywords: Poultry; femur; profitability; live weight; tibiotarsus

\section{Densidade de criação no desempenho e lucratividade de frangos de corte Ross 308}

\section{RESUMO}

Objetivou-se avaliar o efeito da densidade de criação sobre o desempenho produtivo, características de carcaça, produtividade, desenvolvimento ósseo e a lucratividade de frangos de corte Ross 308. O delineamento experimental utilizado foi o inteiramente casualizado com quatro densidades de criação $\left(10,12,14\right.$ e 16 aves $\left.\mathrm{m}^{-2}\right)$ e quatro repetições, e as subparcelas as idades de coleta dos ossos (7, 14, 21, 28, 35 e 42 dias das aves). As variáveis analisadas foram: peso vivo aos 21 e 42 dias, ganho de peso, consumo de ração e conversão alimentar, nos períodos acumulados de 1 a 21 e 1 a 42 dias. Avaliaram-se os pesos e rendimentos de carcaça, cortes comerciais, vísceras comestíveis e da gordura abdominal, a produtividade, o índice de eficiência produtiva, a viabilidade, a lucratividade e também o comprimento, a espessura, o peso e o índice de Seedor dos ossos longos (tibiotarso e fêmur). A produtividade foi maior para as densidades de 14 e 16 aves $\mathrm{m}^{-2}$. A espessura do tibiotarso foi menor na densidade de 12 aves $\mathrm{m}^{-2}$. O aumento da densidade de criação de 10 ou 12 aves $\mathrm{m}^{-2}$ para 14 aves $\mathrm{m}^{-2}$ possibilita maior produtividade por $\mathrm{m}^{-2}$, sem comprometer o desempenho produtivo, as características de carcaça e o desenvolvimento ósseo dos animais, além de ser a densidade de criação com a maior lucratividade, considerando o bem-estar dos frangos de corte da linhagem Ross 308.

Palavras-chave: Avicultura; fêmur; lucratividade; peso vivo; tibiotarso. 


\section{Introduction}

The Brazilian poultry industry is well represented in the world market. However, the poultry sector needed to reevaluate the management, broilers' nutrition, and breeding density criteria to maximize productivity and optimize costs to keep up with its rapid rise. Although the current strains have different requirements, with the revision of the broiler breeding criteria, the reduction in the profit margin has become an important factor, leading the industry to increase the bird stocking rate per square meter to meet the growing sector demand and optimize profitability (Gopinger et al., 2015).

The creation of high-density broilers has been used to increase the poultry farmer's productivity and profitability without increasing the production area and improving the breeding's economic viability. Poultry's increase per $\mathrm{m}^{-2}$ allows producing a greater meat quantity (kg) per useful area (Uzum and Toplu, 2013). According to Gholami et al. (2020), population density is important, as the area underutilization will affect the return on investments in the facilities.

Chicken farmers increasingly need to produce birds with stable development and versatility to meet the wide variety of products in the slaughter line. The Ross 308 broiler line was developed based on these needs because they are robust broilers, fast-growing, good feed conversion, and good carcass yield (Ross, 2018). Also, the Ross 308 strain has great potential for meat production, adequate zootechnical performance, and excellent breast meat quantity and quality (Api et al., 2017).

Due to the search for the production of increasingly early birds, genetic improvement programs are focused on high weight gain and high growth rates. This provokes the accumulation of large loads on relatively immature bones and joints, thus causing bone malformation and, consequently, leg problems (Ponso et al., 2012).

The clients' concern regarding animal welfare in the creation system of the product to be consumed has become more frequent. According to the Terrestrial Animal Health Code, broilers' well-being must be evaluated using parameters based on indicators' analysis results, such as the animal's mortality and growth rate. (OIE, 2019). Other parameters to be considered for assessing animal welfare levels are measured by assessing abnormalities in these animals' legs, which is one of the most serious problems encountered in fastgrowing animals (Gholami et al., 2020).

Given the above, the objective was to evaluate the effect of stocking density on productive performance, carcass characteristics, productivity, bone development, and profitability of Ross 308 broilers.

\section{Material and Methods}

The experiment was carried out in the experimental poultry shed at the Zootechnical Sector of the State University of Mato Grosso do Sul, Cassilândia University Unit $\left(1^{\circ} 07^{\prime} 21^{\prime \prime} \mathrm{S}, 5^{\circ} 43^{\prime} 15^{\prime \prime} \mathrm{W}\right.$ and altitude of $516 \mathrm{~m}$ ), in the period of February 11 to March 25, 2020. The procedures were approved by the Ethics Committee on the Use of Animals (CEUA) of the State University of Mato Grosso do Sul (UEMS) under protocol No. 035/2019.

A genetic group of broilers of the Ross 308 lineage, originating from 55-week-old matrixes, was purchased from the Commercial Incubator of the company Pluma Avícola, located in Cassilândia (MS) municipality, totaling 564 one day old broiler chicks. They were sexed by the company itself, mixed batch, 282 females and 282 males, with an average weight of 43 grams with one day old. The chicks were vaccinated in the hatchery for the following diseases: Gumboro, Marek, Infectious Bronchitis, and Avian Bouba.

The chicks were housed at one day old in boxes, in a conventional shed with fiber cement tiles, 22 meters long by six meters wide and 2.30 meters high, with fans and nebulizers. Each box had $3.0 \mathrm{~m}^{2}$ and, discounting $0.32 \mathrm{~m}^{2}$ for feeders and waterers, $2.68 \mathrm{~m}^{2}$ were available to animals. They were distributed in four treatments, which were the stocking densities: $\mathrm{T} 1$ $=10$ birds $\mathrm{m}^{-2} ; \mathrm{T} 2=12$ birds $\mathrm{m}^{-2} ; \mathrm{T} 3=14$ birds $\mathrm{m}^{-2}$ and $\mathrm{T} 4=16$ birds $\mathrm{m}^{-2}$. Each box was equipped with a heating source (hoods) with $150 \mathrm{~W}$ lamps. First-use wood shavings were used on the floor, approximately $0.08 \mathrm{~m}$ high.

During the first 10 days of the chicks' life, the drinking fountains used were the infant pressure cup and infant tubular feeders, which were subsequently gradually replaced by an automatic pendant feeder and an adult tubular feeder occupying an area of $0.16 \mathrm{~m}^{2}$ each, inside the box. The heating control and the curtains' handling were carried out according to the bird's need. The internal temperature was measured with a maximum and minimum digital thermometer's aid, kept in the shed's center, and monitored twice a day, at 7:30 am and 4:00 pm during the whole experimental period. The minimum and maximum average temperatures from 1 to 21 days were $25.0{ }^{\circ} \mathrm{C}$ and $33.1^{\circ} \mathrm{C}$; from 22 to 35 days were $22.7^{\circ} \mathrm{C}$ and 33.7 ${ }^{\circ} \mathrm{C}$; and from 36 to 42 days were $23.9^{\circ} \mathrm{C}$ and $32.0^{\circ} \mathrm{C}$, respectively.

The average minimum and maximum temperature in the whole poultry-rearing period ( 1 to 42 days) were $24.1^{\circ} \mathrm{C}$ and $33.3{ }^{\circ} \mathrm{C}$, respectively. The diets used in the experiment were all isonutritive based on corn and soybean meal. The three-phase program was used: initial ration (1 to 21 days), growth ration (22 to 35 
days), and final ration (36 to 42 days), whose compositions are shown in Table 1.

During the entire experimental period, feed and water were provided ad libitum for the birds. The productive performance data were obtained and analyzed in the accumulated periods from 1 to 21 and 1 to 42 days old. Bodyweight was obtained by weighing all birds from each repetition (box) at the beginning of the experiment (one day old), 21, and 42 days. The weight gain was obtained by the difference between the final and initial weights on the evaluated period.

The feed consumption was calculated by the difference between the total feed supplied and the final leftovers of each period and corrected by the average number of birds. The feed conversion was calculated by the total feed consumed to the gained weight in the period ratio and corrected for mortality according to Sakomura and Rostagno (2016). The productivity data were expressed in kilograms of live weight per $\mathrm{m}^{2}$ and calculated using the following formula: $\mathrm{MP}=\mathrm{TW} / \mathrm{A}$, where MP is the meat production/area $\left(\mathrm{kg} \mathrm{m}^{-2}\right)$; TW is the total weight of the birds in each box $(\mathrm{kg})$ at 42 days old, and A is the boxes' area $\left(\mathrm{m}^{2}\right)$.

The birds' rearing viability was determined by the number of birds alive within each treatment, given as a percentage. For this, the following formula was used: $\mathrm{RV}=\mathrm{NE}^{*} 100 / \mathrm{NB}$, where $\mathrm{RV}$ is the animals' rearing viability (\%), NE is the total number of birds alive in each treatment at the end of the experiment, and NB is the number of birds placed in each treatment at the beginning of the experiment.

The productive efficiency index (PEI) was calculated using the following formula: $\mathrm{PEI}=((\mathrm{LW} *$ $\mathrm{RV}) /(\mathrm{FC} * \mathrm{AS}) * 100), \mathrm{LW}$ is the live weight $(\mathrm{kg})$, $\mathrm{RV}$ is the rearing viability (\%), FC is the feed conversion of the animals from 1 to 42 days old and AS is the age at slaughter (42 days).

Two birds, a male and a female, were selected at 42 days old, per experimental unit with $\pm 5 \%$ of the average live weight of the repetition, making a total of eight birds per treatment, for the evaluation of carcass weights and yields, commercial cuts, edible viscera, and abdominal fat. After 8 hours of fasting, the birds were desensitized by electronarcosis (shock $220 \mathrm{~V}$ ), followed by bleeding, scalding in boiling water, plucking, and carcass evisceration.

The carcass yield was calculated considering the live weight before slaughter [\% CY $=$ (carcass weight* 100/live weight)] in which the weight of the eviscerated carcass (without the head, feet, and neck) was divided by the live slaughter weight.

Table 1. Percentage and chemical composition of experimental diets for broilers in the initial (1 to 21 days), growth (22 to 35 days), and final (36 to 42 days old) phases.

\begin{tabular}{llll}
\hline Ingredients $(\%)$ & Initial phase & Growth phase & Final phase \\
\hline Ground corn & 53.33 & 54.64 & 62.10 \\
Soybean crumb & 39.94 & 37.53 & 30.49 \\
Soybean oil & 2.91 & 4.71 & 4.70 \\
Dicalcium phosphate & 1.61 & 1.10 & 0.90 \\
Calcitic limestone & 1.40 & 1.43 & 1.33 \\
Common salt & 0.45 & 0.33 & 0.25 \\
DL-Methionine & 0.21 & 0.06 & 0.03 \\
Mineral-vitamin supplement ${ }^{1}$ & 0.15 & 0.20 & 0.20 \\
\hline Total & 100.00 & 100.00 & 100.00 \\
\hline Calculated Nutritional Values & & & 3,200 \\
\hline Metabolizable energy (kcal / kg) & 2,950 & 3,100 & 18.50 \\
Brute protein (\%) & 22.00 & 21.00 & 0.80 \\
Calcium (\%) & 1.00 & 0.90 & 0.30 \\
Available phosphorus (\%) & 0.45 & 0.35 & 0.60 \\
Methionine + Cystine (\%) & 0.90 & 0.72 & 0.32 \\
Methionine (\%) & 0.53 & 0.38 & 0.85 \\
Lysine (\%) & 1.24 & 1.00 & 172.97 \\
EM: PB Ratio & 134.10 & 147.62 & $9.50001 ; \mathrm{V}$
\end{tabular}

${ }^{1}$ Mineral-vitamin supplement (content per kg of product) - Vitamin A - 3,000,000 Ul; Vitamin E - 9,500 Ul; Vitamin B - 588 mg; Vitamin $\mathrm{B}_{2}$ - 1,660 mg; Vitamin $\mathrm{B}_{6}-792 \mathrm{mg}$; Vitamin $\mathrm{B}_{12}$ - 4,150 mcg; Vitamin K3 - $520 \mathrm{mg}$; Vitamin D3 - 800 Ul; Calcium pantothenate - 3,230 mg; Niacin - 9,800 mg; Folic acid - 200 mg; Biotin - 20 mg; Zinc - 13 g; Iron - 13 g; Manganese - 15 g; Copper - 3,120 mg; Iodine - 254 mg; Cobalt - 48 mg; Selenium - 88 mg; Ethoxyquin - 52 mg; B.H.A - 40 mg; Vehicle Q.S, P. - 1,000 mg 
The chest, back, thigh, drumstick, wing, wing leg, and edible viscera (liver, heart, and gizzard) cuts had their respective yields determined, depending on the carcass weight $[\% \quad \mathrm{PY}=$ (weight of the part*100/carcass weight)], where PY is part yield. The abdominal fat collected was constituted by the adipose tissue present from the gizzard to the cloaca and cloacal pouch's content. Its performance was determined according to the carcass weight.

For evaluation of bone development, two birds were sacrificed at 7, 14, 21, 28, 35, and 42 days old (a male and a female), with an average weight of the box ( \pm $5 \%$ ), for the collection of the long bones (tibiotarsus and right femur). After collection, the bones were frozen being thawed at the time of the analyzes with the adhered muscle tissue removed. In this way, the tibiotarsus and femurs were taken for bone evaluations.

A precision semi-analytical scale $( \pm 0.01 \mathrm{~g})$ was used to measure bone weight. Both bone length and thickness were measured with the aid of a digital caliper $(0.1 \mathrm{~mm})$. The length was measured by taking the longest distance between the epiphyses and the thickness by taking the bone's central point. The measurements were always made at the same points and by the same person in all bones. The Seedor index was calculated (Seedor et al., 1991) using the bone's weight and length with the following formula: bone weight $(\mathrm{mg}) /$ bone length (mm).

The experimental design used was completely randomized (CRD) in a split-plot scheme with four treatments, represented by the stocking densities 10,12 , 14, and 16 birds $\mathrm{m}^{-2}$, and the subplots, the bone collections ages $(7,14,21,28,35$ and 42 days old of the birds), with four replicates each. The performance data, weights and yields of the carcass, cuts, edible viscera, and productivity were subjected to analysis of variance with the averages being compared through the Tukey test at the $5 \%$ probability level.

The bone development data obtained were previously tested for normality using the KolmogorovSmirnov test. When this assumption was not verified, the data were transformed using the Box-Cox transformation family, given by the equation: $y \lambda=(\mathrm{y} \lambda$ 1) $/ \lambda$. Subsequently, to evaluate differences between the broilers' rearing density treatments, the variance analysis (ANOVA) was performed with the averages being compared through the Tukey test at the 5\% probability level.

Statistical analyzes were performed with the aid of the Sisvar Computational Program (Ferreira, 2011). Besides, a study's economic analysis was carried out, based on an aviary for the creation of standard broilers, with $2100 \mathrm{~m}^{2}$ with the results being simulated for the four breeding densities $\left(10,12,14\right.$, and 16 birds $\left.\mathrm{m}^{-2}\right)$ evaluated, employing the results obtained on the birds in the different treatments, at 42 days of age. Profitability analysis was made using financial expenditure from chicks and feed. The financial expenditure calculation of a feed kilogram was carried out based on the price of the raw material used and the price of a $\mathrm{kg}$ of live chicken based on the agricultural commodities' quotation (Agrolink, 2020) in September 2020, and the purchase price of one-day-old chicks from the poultry hatchery of the Pluma Avícola Company, located in the city of Cassilândia (MS). The average feed cost calculated was US $\$ 0.31 / \mathrm{kg}$; the price of live chicken, US $\$ 0.79 / \mathrm{kg}$; and the one-day-old chick's price, \$ 0.29 a unit.

\section{Results and Discussion}

The characteristics of productive performance (live weight, weight gain, feed intake, and feed conversion) in the accumulated periods from 1 to 21 and 1 to 42 days are shown in Table 2.

From 1 to 21 days, the increase in stocking density did not influence the animals' performance (Table 2). Disagreeing with the results of Oliveira et al. (2012), who evaluated the same parameters and breeding period, found better results for animals raised in the density of 10 birds $\mathrm{m}^{-2}$ compared to the density of 16 birds $\mathrm{m}^{-2}$.

For the total broiler breeding period from 1 to 42 days (Table 2), the breeding density did not influence the animals' productive performance for any of the evaluated parameters due to the careful and daily animals' handling, fundamental for obtaining broilers' high-density rearing satisfactory results. Disagreeing with most authors (Oliveira et al., 2012; Uzum and Toplu, 2013; Astaneh et al., 2018), who observed lower weight gain, feed consumption, and weight gain as the number of birds $\mathrm{m}^{-2}$ rises.

The evaluated parameters of LW, FI, WG, and FC, in the total period of creation ( 1 to 42 days old), had average values between the densities of $10,12,14$, and 16 birds $\mathrm{m}^{-2}$ of 2,656 g, 4,474 g, 2,613 g, and $1.713 \mathrm{gg}^{-}$ ${ }^{1}$, respectively. Compared to the performance objectives manual results for broilers Ross 308 (Ross, 2017), for 42 days old in mixed batches of 2,920 g, $4,761 \mathrm{~g}, 2,877 \mathrm{~g}$, and $1.631 \mathrm{~g} \mathrm{~g}^{-1}$, respectively, less productive performance was observed. This result is associated with the poultry house high temperatures, with recorded average minimum and maximum temperatures during the experiment of 24.1 and $33.3^{\circ}$ $\mathrm{C}$, respectively, above the ideal for the birds' thermal comfort. Ross (2018) mentions that the ideal temperature should be $20^{\circ} \mathrm{C}$ from the animals' 27 days old. 
Table 2. Cumulative live weight (LW) performance, feed intake (FI), weight gain (WG), and feed conversion (FC) of Ross 308 broilers reared at different breeding densities, in periods from 1 to 21 and 1 to 42 days old.

\begin{tabular}{|c|c|c|c|c|c|c|}
\hline \multicolumn{7}{|c|}{ Rearing Densities (birds $\mathrm{m}^{-2}$ ) } \\
\hline & 10 & 12 & 14 & 16 & $\mathrm{P}$ & $\mathrm{CV}(\%)$ \\
\hline & \multicolumn{6}{|c|}{ Period from 1 to 21 days } \\
\hline $\mathrm{LW}$ at 21 days $(\mathrm{g})$ & 941 & 865 & 951 & 939 & NS & 11.76 \\
\hline $\mathrm{FI}(\mathrm{g})$ & 1,225 & 1,095 & 1,211 & 1,180 & NS & 12.40 \\
\hline WG (g) & 897 & 822 & 908 & 895 & NS & 12.34 \\
\hline \multirow[t]{2}{*}{$\mathrm{FC}(\mathrm{g} / \mathrm{g})$} & 1.370 & 1.330 & 1.335 & 1.317 & NS & 1.92 \\
\hline & \multicolumn{6}{|c|}{ Period from 1 to 42 days } \\
\hline LW at 42 days (g) & 2,822 & 2,573 & 2,660 & 2,570 & NS & 5.93 \\
\hline $\mathrm{FI}(\mathrm{g})$ & 4,669 & 4,288 & 4,570 & 4,367 & NS & 7.36 \\
\hline WG $(g)$ & 2,779 & $2,529^{b}$ & 2,617 & 2,526 & NS & 6.03 \\
\hline $\mathrm{FC}(\mathrm{g} / \mathrm{g})$ & 1.679 & 1.696 & 1.747 & 1.728 & NS & 3.43 \\
\hline
\end{tabular}

NS: Non-significant effect by the Tukey test at $5 \%$ probability. $\mathrm{CV}$ : Coefficient of variation.

Temperatures above the ideal may have caused caloric stress in the animals, reducing feed intake and, consequently, the animal weight. These data agree with those obtained by Bonamingo et al. (2011), who evaluated the chickens' welfare degree in different stocking densities and observed that the decrease in environmental quality, caused by the lack of effective control over environmental conditions, caused a reduction in the animals' performance.

The absence of the density effect on feed conversion in the studied periods corroborates the results of Henrique et al. (2017), who worked with the same densities for broilers of the Cobb 500 strain. However, they disagree with Astaneh et al. (2018), who worked with the Ross 308 strain using housing density of 12 and 18 birds $\mathrm{m}^{-2}$ and found worse results for feed intake and conversion in the period from 1 to 42 days, with an increase in the birds' quantity per square meter.

The results of weight and yield of carcass, breast, back, thigh, drumstick, wing, and wing drumette (Table 3 ) were superior to that recommended by the lineage (Ross, 2017) for the main commercial cuts not differing between the densities of Ross 308 broiler chickens studied. According to Ross (2017), the expected value for carcass, breast, thigh, drumstick, and wing yield is $73.51 \% ; 22.98 \% ; 9.81 \% ; 13.91 \%$, and $7.74 \%$, respectively. On average, those found in the current study were between densities, $74.12 \% ; 31.27 \% ; 13.95$ $\% ; 17.76 \%$, and $5.07 \%$, respectively, for mixed batch chickens with a live weight between 2,600 and 2,800 grams.

Marcu et al. (2014) found similar results for carcass yield of the Ross 308 strain obtaining an average value of $74.04 \%$, close to that found in the current study of $74.12 \%$ for the rearing densities investigated.

The rearing densities studied did not influence edible viscera's weight and yield, but it did interfere with abdominal fat deposition (Table 3). Birds reared at a density of 16 birds $\mathrm{m}^{-2}$ had worse results for abdominal fat when compared to birds reared at a density of 12 birds $\mathrm{m}^{-2}$ and similar to those of 10 and 14 birds $\mathrm{m}^{-2}$ densities. Api et al. (2017) worked with the Ross 308 strain and obtained $2.56 \%$ of abdominal fat, with higher values than those found for this parameter in all investigated densities averaging $1.76 \%$. This data demonstrates high carcass utilization in all studied densities since the abdominal fat present in the carcass is not a desired factor as it has no economic value.

Broiler productivity at 42 days old was influenced by different rearing densities (Table 4). The increase in the number of birds $\mathrm{m}^{-2}$ increased the $\mathrm{kg} \mathrm{m}^{-2}$ production. There was an increase of $10.62,30.88$, and $45.06 \%$, respectively, in flock productivity, with an increase in density from 10 to 12,14 , and 16 birds $\mathrm{m}^{-2}$. These results corroborate the Astaneh et al. (2018) findings, who observed higher productivity per $\mathrm{m}^{2}$ for highdensity reared birds.

It is important to pay attention to animal welfare because, according to the Brazilian Poultry Union (UBA), productivity should not exceed $39 \mathrm{~kg} \mathrm{~m}^{-2}$ so that birds can express their normal behavior (UBA, 2008). However, the average productivity value obtained in the 16 birds $\mathrm{m}^{-2}$ rearing density (Table 4 ) was $41.24 \mathrm{~kg} \mathrm{~m}^{-2}$, higher than that recommended by UBA. Therefore, this density is not indicated since it harms the chickens' welfare. The creative viability was not influenced by the evaluated stocking densities (Table 4).

With proper planning and animal handling, it is possible to obtain high rearing viability levels, increasing from 10 to 16 birds $\mathrm{m}^{-2}$ in a conventional broiler poultry house. Proper management practices are one of the main variables for successful production, and careful and daily animal behavior monitoring is essential for high viability rates. 
Table 3. Average carcass weight and yield, breast, back, thigh, drumstick, wing, wing drumette, edible viscera, and abdominal fat of Ross 308 broilers reared at different breeding densities at 42 days old.

\begin{tabular}{|c|c|c|c|c|c|c|}
\hline Variables & 10 birds $\mathrm{m}^{-2}$ & 12 birds $\mathrm{m}^{-2}$ & 14 birds $\mathrm{m}^{-2}$ & 16 birds $\mathrm{m}^{-2}$ & $\mathrm{P}$ & $\mathrm{CV}(\%)$ \\
\hline \multicolumn{7}{|c|}{ Weight (grams) } \\
\hline Carcass & 1,970 & 1,860 & 1,964 & 1,977 & NS & 7.99 \\
\hline Breast & 611 & 572 & 632 & 622 & NS & 12.40 \\
\hline Back & 400 & 380 & 379 & 353 & NS & 11.98 \\
\hline Thigh & 283 & 257 & 273 & 271 & NS & 8.00 \\
\hline Drumstick & 344 & 336 & 342 & 357 & NS & 8.46 \\
\hline Wing & 102 & 93 & 101 & 99 & NS & 5.75 \\
\hline Wing drumette & 118 & 116 & 119 & 123 & NS & 7.94 \\
\hline Liver & 47 & 46 & 52 & 49 & NS & 11.69 \\
\hline Heart & 11 & 10 & 11 & 10 & NS & 16.94 \\
\hline Gizzard & 33 & 30 & 34 & 31 & NS & 10.14 \\
\hline Abdominal Fat & $35 \mathrm{ab}$ & $22 b$ & $36 \mathrm{ab}$ & $45 \mathrm{a}$ & 0.0214 & 25.46 \\
\hline \multicolumn{7}{|l|}{ Performance $(\%)$} \\
\hline Carcass & 73.73 & 73.63 & 73.80 & 75.30 & NS & 2.28 \\
\hline Breast & 30.88 & 30.72 & 32.08 & 31.41 & NS & 5.77 \\
\hline Back & 20.44 & 20.28 & 19.31 & 17.92 & NS & 8.37 \\
\hline Thigh & 14.34 & 13.84 & 13.91 & 13.72 & NS & 5.27 \\
\hline Drumstick & 17.39 & 18.13 & 17.49 & 18.01 & NS & 5.90 \\
\hline Wing & 5.17 & 5.01 & 5.12 & 4.99 & NS & 4.85 \\
\hline Wing drumette & 6.00 & 6.27 & 6.09 & 6.24 & NS & 7.54 \\
\hline Liver & 2.37 & 2.48 & 2.65 & 2.47 & NS & 10.62 \\
\hline Heart & 0.53 & 0.52 & 0.58 & 0.48 & NS & 18.51 \\
\hline Gizzard & 1.68 & 1.63 & 1.71 & 1.56 & NS & 9.32 \\
\hline Abdominal Fat & $1.77 \mathrm{ab}$ & $1.15 \mathrm{~b}$ & $1.84 \mathrm{ab}$ & $2.26 \mathrm{a}$ & 0.0112 & 21.69 \\
\hline
\end{tabular}

a-b averages within each line, for each variable, followed by different letters, differ $(\mathrm{P}<0.05)$ by the Tukey test at the $5 \%$ probability level.

NS: Non-significant effect by the Tukey test at $5 \%$ probability.

CV: Coefficient of variation.

Table 4. Productivity, rearing viability, and productive efficiency index (PEI) of Ross 308 broilers reared in different rearing densities.

\begin{tabular}{lllllll}
\hline Rearing Densities (birds $\left.\mathrm{m}^{-2}\right)$ & \multicolumn{7}{l}{} & & \\
\hline Parameters & 10 & 12 & 14 & 16 & $\mathrm{P}$ & $\mathrm{CV}(\%)$ \\
\hline Productivity $\left(\mathrm{kg} \mathrm{m}^{-2}\right)$ & $28.43 \mathrm{~b}$ & $31.45 \mathrm{~b}$ & $37.21 \mathrm{a}$ & $41.24 \mathrm{a}$ & 0.0001 & 5.63 \\
Rearing Viability (\%) & 100.00 & 99.42 & 98.96 & 100.00 & NS & 1.20 \\
PEI & 400 & 360 & 359 & 355 & NS & 6.20 \\
\hline
\end{tabular}

a-b averages within each line, for each variable, followed by different letters, differ $(\mathrm{P}<0.05)$ by the Tukey test at $5 \%$ probability level.

NS: Non-significant effect by the Tukey test at $5 \%$ probability.

CV: Coefficient of variation.

These parameters are of fundamental importance for broilers' rearing to have financial viability since the profit margin per animal in the activity is small. The PEI did not differ between the breeding densities studied (Table 4). This parameter evaluates birds' performance, used by most broiler integrators to calculate the producers' remuneration.

The higher the PEI, the higher the payment the integrated producer receives.In all breeding densities, similar PEI values obtained by poultry companies with high technology standards were verified. Bruno et al. (2012), working with the Ross 308 strain, evaluated the performance of broilers fed diets containing probiotics found an average PEI of 350.28, a lower value than those found in the current study, in all evaluated rearing densities. There was no interaction $(\mathrm{P}>0.05)$ between the stocking density and the birds' age for any bone parameter evaluated (Tables 5, 6, 7, and 8).

Bone length, thickness, weight, and the Seedor index increased with advancing bird age, corroborating data from Henrique et al. (2017), who evaluated the effect of stocking density on broilers' bone development of the Cobb $500 \AA$ strain. They obtained at 42 days old the following average values for tibiotarsus and femur length of $102.92 \mathrm{~mm}$ and $78.63 \mathrm{~mm}$, respectively; 8.39 $\mathrm{mm}$ and $9.16 \mathrm{~mm}$ thickness; a weight of $15.57 \mathrm{mg}$ and 
$13.74 \mathrm{mg}$ and Bone Seedor Index of $0.15 \mathrm{mg} / \mathrm{mm}$ and $0.17 \mathrm{mg} / \mathrm{mm}$, all values lower than those found in this study. These results may have been caused by the fact that the Ross 308 strain showed higher animal productive performance than the Cobb $500^{\circledR}$ strain during the entire breeding period, resulting in greater measures for the evaluated bone parameters since bone tissue follows muscle growth tissue in birds.

The broilers' tibiotarsus and femur length did not differ between the studied rearing densities (Table 5). These results are similar to those of Oliveira et al. (2012), who worked with the stocking densities of 10 and 16 birds $\mathrm{m}^{-2}$ and concluded that the two stocking densities evaluated did not influence the long bones' length.

There was no difference between rearing densities for femur thickness. However, there was a significant difference in tibiotarsus thickness (Table 6). The animals reared at a density of 12 birds $\mathrm{m}^{-2}$ showed less tibiotarsus thickness, evidencing a significant difference to those reared at 10 birds $\mathrm{m}^{-2}$; thus, it was similar to those reared at 14 and 16 birds $\mathrm{m}^{-2}$.

Applegate and Lilburn (2002), working with the commercial Arbor Acres and Ross broiler lines' femur and tibiotarsus growth, observed that the femur grew faster than the tibiotarsus until the 35 days old completing their bone maturation stage first. Cristo et al. (2017) stated the existence of a relationship between greater tibiotarsus cross-sectional areas and lower rearing densities.

The weight and Seedor index of the long bones were not influenced by the breeding densities ( $\mathrm{P}$ > $0.05)$, but age determined significant differences (Tables 7 and 8). As the days go by, the long bones' length and weight increase, making them denser, as observed for the Seedor index values. Henrique et al. (2017) evaluated the broilers' bone development of the Cobb $500 \AA$ strain reared in the densities of 10, 12, 14, and 16 birds $\mathrm{m}^{-2}$ and concluded that the four breeding densities evaluated did not influence the weight and the Seedor index of the studied bones.

Based on the results presented for the birds' bone characteristics of the Ross 308 strain (Tables 5, 6, 7, and 8), it was evident that the increase in rearing density from 10 birds $\mathrm{m}^{-2}$ to 16 birds $\mathrm{m}^{-2}$ did not reflect damage to bone characteristics. According to Mendes et al. (2012), it is necessary to define methodologies to measure the locomotor problems' incidence in broilers since animal welfare concern has become a commercial strategy for the food industry's conquest of consumers.
Table 5. Means and analysis of variance for the effect of stocking density $\left(10,12,14\right.$, and 16 birds $\left.\mathrm{m}^{-2}\right)$ and age on the long bones' (tibiotarsus and femur) length of Ross 308 broilers.

\begin{tabular}{lll}
\hline Treatments & Tibiotarsus & Femur Length \\
\hline Rearing Density & & \\
\hline 10 & 79.88 & 58.63 \\
12 & 78,34 & 58.17 \\
14 & 79,08 & 57.69 \\
16 & 79,46 & 58.24 \\
\hline Age (days) & & \\
\hline 7 & $43.03 \mathrm{f}$ & $31.36 \mathrm{f}$ \\
14 & $58.83 \mathrm{e}$ & $44.23 \mathrm{e}$ \\
21 & $74.60 \mathrm{~d}$ & $54.52 \mathrm{~d}$ \\
28 & $87.31 \mathrm{c}$ & $63.92 \mathrm{c}$ \\
35 & $99.42 \mathrm{~b}$ & $73.12 \mathrm{~b}$ \\
42 & $111.94 \mathrm{a}$ & $81.94 \mathrm{a}$ \\
\hline CV (\%) & 3.48 & 3.74 \\
\hline Variation & \multicolumn{2}{c}{ Probability $>$ Fc } \\
\hline Density & NS & NS \\
Age & $<0.0000$ & $<0.0000$ \\
Density x Age & NS & NS \\
\hline
\end{tabular}

a-f: Means within each column, for each variable, followed by different letters differ $(\mathrm{P}<0.05)$ by the Tukey test at $5 \%$ probability level.

NS: Non-significant effect by the Tukey test at $5 \%$ probability. $\mathrm{CV}$ : Coefficient of variation.

Table 6. Averages and variance analysis stocking density (10, 12,14 , and 16 birds $\mathrm{m}^{-2}$ ) effect and age on the long bones' (tibiotarsus and femur) thickness of Ross 308 broilers.

\begin{tabular}{lll}
\hline Treatments & Tibiotarsus & Femur \\
\hline Rearing Densities & & \\
\hline 10 & $6.72 \mathrm{a}$ & 7.01 \\
12 & $6.39 \mathrm{~b}$ & 6.76 \\
14 & $6.50 \mathrm{ab}$ & 6.81 \\
16 & $6.59 \mathrm{ab}$ & 6.87 \\
\hline Age (days) & & \\
\hline 7 & $2.84 \mathrm{f}$ & $2.97 \mathrm{f}$ \\
14 & $4.65 \mathrm{e}$ & $4.92 \mathrm{e}$ \\
21 & $6.63 \mathrm{~d}$ & $6.82 \mathrm{~d}$ \\
28 & $7.49 \mathrm{c}$ & $7.87 \mathrm{c}$ \\
35 & $8.48 \mathrm{~b}$ & $8.79 \mathrm{~b}$ \\
42 & $9.21 \mathrm{a}$ & $9.79 \mathrm{a}$ \\
\hline CV (\%) & 9.31 & 9.00 \\
\hline Variation Source & Probability $>$ Fc & \\
\hline Density & 0.0450 & NS \\
Age & $<0.0000$ & $<0.0000$ \\
Density x Age & NS & NS \\
\hline
\end{tabular}

a-f: Means within each column, for each variable, followed by different letters differ $(\mathrm{P}<0.05)$ by the Tukey test at the level of $5 \%$ probability.

NS: Non-significant effect by the Tukey test at $5 \%$ probability. $\mathrm{CV}$ : Coefficient of variation 
Table 7. Averages and variance analysis for the stocking density $\left(10,12,14\right.$, and 16 birds $\left.\mathrm{m}^{-2}\right)$ effect and age on the long bones' (tibiotarsus and femur) weight of Ross 308 broilers.

\begin{tabular}{|c|c|c|}
\hline Treatments & $\begin{array}{l}\text { Tibiotarsus } \\
\text { Weight(mg) }\end{array}$ & $\begin{array}{l}\text { Femur } \\
\text { Weight(mg) }\end{array}$ \\
\hline \multicolumn{3}{|l|}{$\begin{array}{l}\text { Rearing Densities } \\
\left(\text { birds } \mathrm{m}^{-2}\right)\end{array}$} \\
\hline 10 & 10.12 & 7.36 \\
\hline 12 & 9.75 & 7.05 \\
\hline 14 & 9.77 & 7.06 \\
\hline 16 & 10.15 & 7.22 \\
\hline \multicolumn{3}{|l|}{ Age (days) } \\
\hline 7 & $1.14 \mathrm{f}$ & $0.81 \mathrm{f}$ \\
\hline 14 & $3.62 \mathrm{e}$ & $2.61 \mathrm{e}$ \\
\hline 21 & $7.40 \mathrm{~d}$ & $5.29 \mathrm{~d}$ \\
\hline 28 & $11.41 \mathrm{c}$ & $8.07 \mathrm{c}$ \\
\hline 35 & $15.74 b$ & $11.19 \mathrm{~b}$ \\
\hline 42 & $20.37^{a}$ & $15.08 \mathrm{a}$ \\
\hline $\mathrm{CV}(\%)$ & 8.43 & 9.33 \\
\hline Variation Source & \multicolumn{2}{|c|}{ Probability $>$ Fc } \\
\hline Density & NS & NS \\
\hline Age & $<0.0000$ & $<0.0000$ \\
\hline Density x Age & NS & NS \\
\hline
\end{tabular}

a-f: Means within each column, for each variable, followed by different letters differ $(\mathrm{P}<0.05)$ by the t-test at the 5\% probability level.

NS: Non-significant effect by the Tukey test at $5 \%$ probability.

$\mathrm{CV}$ : Coefficient of variation.
The economic analysis (Table 9) shows that the total cost increased as the number of birds $\mathrm{m}^{-2}$ raised, comparing the four studied densities, since, as the animal stocking rate increases, the number of animals housed and the feed to be purchased proportionally increases.

Considering that there was no difference in feed conversion and feed intake (Table 2), in the period from 1 to 42 days, the costs variable increased as the amount of meat $\mathrm{m}^{-2}$ grew.

When comparing the densities of 10 and 16 birds $\mathrm{m}^{2}$, which are respectively the lowest and the highest density of reared breeding, it was observed that the flock of 16 birds $\mathrm{m}^{-2}$ resulted in a profit of US \$ $2,459.05$, compared to the 10 birds $\mathrm{m}^{-2}$ density.

Since profitability varies according to the day quotation, the feed price, and the chicken $\mathrm{kg}$, the density of more profitable rearing can change due to the prices practiced on the cost calculating date.

Consumer concerns about animal welfare have led to clients' demands to the food industry for information about how animals have been reared. Based on the UBA productivity values so that the birds can express their normal behavior (UBA, 2008), the density of 14 birds $\mathrm{m}^{-2}$ was the one with the highest profitability (Table 9), considering the animals' wellbeing.

Table 8. Means and analysis of variance for the effect of stocking density $\left(10,12,14\right.$, and 16 birds $\left.\mathrm{m}^{-2}\right)$ and age on the Seedor index of long bones (tibiotarsus and femur) of Ross 308 broilers

\begin{tabular}{|c|c|c|}
\hline Treatments & Tibiotarsus Seedor Index & Femur Seedor Index \\
\hline \multicolumn{3}{|c|}{ Rearing Densities (birds $\mathrm{m}^{-2}$ ) } \\
\hline 10 & 0.11 & 0.11 \\
\hline 12 & 0.11 & 0.10 \\
\hline 14 & 0.11 & 0.11 \\
\hline 16 & 0.11 & 0.11 \\
\hline \multicolumn{3}{|l|}{ Age (days) } \\
\hline 7 & $003 f$ & $0.03 \mathrm{f}$ \\
\hline 14 & $0.06 \mathrm{e}$ & $0.06 \mathrm{e}$ \\
\hline 21 & $0.10 \mathrm{~d}$ & $0.10 \mathrm{~d}$ \\
\hline 28 & $0.13 \mathrm{c}$ & $0.13 \mathrm{c}$ \\
\hline 35 & $0.16 b$ & $0.15 b$ \\
\hline 42 & $0.18^{\mathrm{a}}$ & $0.18 \mathrm{a}$ \\
\hline $\mathrm{CV}(\%)$ & 9.89 & 10.01 \\
\hline Variation Source & Probability > Fc & \\
\hline Density & NS & NS \\
\hline Age & $<0.0000$ & $<0.0000$ \\
\hline Density x Age & NS & NS \\
\hline
\end{tabular}

a-f: Means within each column, for each variable, followed by different letters differ $(\mathrm{P}<0.05)$ by the Tukey test at $5 \%$ probability level. $\mathrm{CV}$ : Coefficient of variation. 
Table 9. Stocking density estimation on profitability and production costs (US \$) of Ross 308 broilers at 42 days old, estimated in a conventional shed of $2,100 \mathrm{~m}^{2}$.

\begin{tabular}{|c|c|c|c|c|c|}
\hline \multirow[t]{2}{*}{ Factor } & \multirow[t]{2}{*}{ Unit Price (US\$) } & \multicolumn{4}{|c|}{ Density (birds $\mathrm{m}^{-2}$ ) } \\
\hline & & 10 & 12 & 14 & 16 \\
\hline Housed birds & - & 21,000 & 25,200 & 29,400 & 33,600 \\
\hline Slaughter birds & - & 21,000 & 25,054 & 29,094 & 33,600 \\
\hline Productivity kg/m² & - & 28.43 & 31.45 & 37.21 & 41.24 \\
\hline Total Productivity kg & - & $59,703.00$ & $66,045.00$ & $78,141.00$ & $86,604.00$ \\
\hline Average feed intake per bird (kg) & & 4.67 & 4.29 & 4.57 & 4.37 \\
\hline Chicken Price (US\$/kg) & 0.79 & $47,332.11$ & $52,360.00$ & $61,949.62$ & $68,659.03$ \\
\hline $\begin{array}{l}\text { Financial expenditure } \\
\text { of chicks (US\$) }\end{array}$ & 0.29 & 6054,05 & 7264,86 & 8475,68 & 9686,49 \\
\hline $\begin{array}{l}\text { Financial expenditure } \\
\text { of the feed (US } \$ / \mathrm{kg})\end{array}$ & 0.31 & $30,250.32$ & $33,169.15$ & $41,047.68$ & $45,485.76$ \\
\hline Total cost (US\$) & - & $36,304.37$ & $40,434.01$ & $49,523.36$ & $55,172.25$ \\
\hline Net Revenue (US\$) & - & $11,027.73$ & $11,925.98$ & $12,426.27$ & $13,486.78$ \\
\hline
\end{tabular}

\section{Conclusions}

The increase in stocking density of 10 or 12 birds $\mathrm{m}^{2}$ to 14 birds $\mathrm{m}^{2}$ allows greater productivity per $\mathrm{m}-2$ without compromising the productive performance, the carcass characteristics, and the animals' bone development. This value is the most profitable breeding density considering the welfare of Ross 308 broilers.

\section{Authors' Contribution}

Higor Jonathan de Oliveira Silva and Andréia Fróes Galuci Oliveira de Souza in the whole experimental and written part of the paper.

Elis Regina de Moraes Garcia and Meiby Carneiro de Paula Leite in writing the paper.

Leticia Gabriela Talhaferro Cassuci, Elyan Carlos da Silva Domingues, Ana Letícia Ribeiro Marques, João Paulo Gomes dos Santos, Gabriela da Silva da Costa, Dayane Camargo Machado and Maria Vitória Silva in the whole experimental part.

\section{Acknowledgments}

This work was carried out with the support of the Institutional Scholarship Program for Graduate Students at the State University of Mato Grosso do Sul (PIBAP/UEMS).

\section{Bibliographic References}

Agrolink. Cotações. https://www.agrolink.com.br/cotacoes/. (acessado em 30 de setembro de 2020).

Api, I., Takahashi, S.E., Mendes, A.S., Paixão, S.J., Refati, R., Restelatto, R. 2017. Effect of strains and sexing on performance and carcass yield of broilers. Ciência Animal
Brasileira, 18, 1-10. DOI: http://dx.doi.org/10.1590/1089$6891 v 18 \mathrm{e}-32691$.

Applegate, T.J., Lilburn, M.S. 2002 Growth of the femur and tibia of a commercial broiler line. Poultry Science, 81(9), 1289-1294. DOI: https://doi.org/ 10.1093 / ps / 81.9.1289.

Astaneh, I,Y., Chamani, M., Mousavi, S.N., Sadeghi, A.A., Afshar, M.A. 2018. Effects of stocking density on performace and immunity in Ross 308 broiler chickens. Kafkas Universitesi Veteriner Fakultesi Dergisi, 24(4), 483-489. DOI: https://doi.org/10.9775/kvfd.2017.18869.

Bonamingo, A., Silva, C.B.S., Molento, C.F.M. 2011. Grau de bem-estar relativo de frangos em diferentes densidades de lotação. Brazilian Journal of Veterinary Research and Animal Science, 63(6), 1421-1428. DOI: http://dx.doi.org/10.1590/S0102-09352011000600020.

Bruno, J.B.C., Albuquerque, R., Raspantini, L.E., Kobashigawa, E., Neto, M.A.T., Araújo, L.F., Rodrigueiro, R.J.B. 2012. Avaliação do desempenho de frangos de corte alimentados com rações contendo probióticos e diferentes níveis de nucleotídeos. Brazilian Journal of Veterinary Research and Animal Science, 49(1), 5-11. DOI: https://doi.org/10.11606/issn.2318-3659.v49i1p5-11.

Cristo, A.B., Schimidt, J.M., Perini, R., Mora, M.; Marques, P.F.S., Santos, A.L., Fernandes, J.I.M. 2017. Efeito da densidade de alojamento sobre a incidência de pododermatites e características ósseas de frangos de corte criados em aviários Dark House. Revista Brasileira de Saúde e Produção Animal, 18(1), 161-173. DOI: https://doi.org/10.1590/s151999402017000100015 .

Ferreira, D.F. 2011. Sisvar: a computer statistical analysis system. Ciência e Agrotecnologia. UFLA, 35(6), 1039-1042. DOI: http://dx.doi.org/10.1590/S1413-70542011000600001.

Gholami, M., Chamani, M., Seidavi, A., Sadeghi, A.A., Aminafschar, M. 2020. Effects of stocking density and environmental conditions on performance, immunity,carcase characteristics, blood constitutes, and economical parameters of cobb 500 strain broiler chickens. Italian Journal of Animal 
Science, $\quad$ 19(1), 524-535, $\quad$ DOI: https://doi.org/10.1080/1828051X.2020.1757522.

Gopinger, E., Avila, V.S., Perondi, D., Catalan, A.A.S., Krabbe, E.L., Roll, V.F.B. 2015. Performance, carcass characteristics and litter moisture in broilers housed at two densities. Acta Scientiarum Animal Sciences, 37(1), 35-39. DOI: http://dx.doi.org/10.4025/actascianimsci.v37i1.24732.

Henrique, C.S., Oliveira, A.F.G., Ferreira, T.S., Silva, E.S., Mello, B.F.F.R., Andrade, A.F., Martins, V.S.F., Paula, F.O., Garcia, E.R.M., Bruno, L.D.G. 2017. Effect of stocking density on performance, carcass yield, productivity, and boné development in broiler chickens Cobb500 ${ }^{\circledR}$. Semina: Ciências Agrárias, 38(4), 2705-2718. DOI: http://dx.org/10.5433/16790359.2017v38n4Supl1p2705.

Marcu, A., Stef, L., Dumitrescu, G., Ciochinã, L.P., Dronca, D., Pet, I., Baul, S., Marcu, A. 2014. Influence of Nutrition, Sex and Slaughter Age on the Carcass Characteristic at Broiler Chicken Ross-308. Scientific Papers Animal Science and Biotechnologies, 47(2), 271-278. http://www.spasb.ro/index.php/spasb/article/view/1767 (acessado em 4 de janeiro de 2021)

Mendes, A.S., Paixão, S.J.A, Marostega, J.B, Restelatto, R.C, Oliveira, P.A.V. \& Possenti, J.C. 2012. Mensuração de problemas locomotores e de lesões no coxim plantar em frangos de corte. Archivos de Zootecnia, 61(234), 217- 228. DOI: http://dx.doi.org/10.4321/S0004-05922012000200006.

Oliveira, A.F.G., Bruno, L.D.G., Garcia, E.R.M., Leite, M.C.P., Ton, A.P.S., Lorençon, L. 2012. Efeito da densidade de criação e do grupo genético sobre o desempenho e o desenvolvimento ósseo de frangos de corte. Scientia Agraria Paranaensis, 11(1), 49-64. DOI: https://doi.org/10.18188/sap.v11i1.6353.

OIE. WORD ORGANISATION FOR ANIMAL HEALTH. 2019. Código sanitário dos animais terrestres. https://www.oie.int/es/normas/codigo-terrestre/ (acessado em 17 de julho de 2020)
Ponso, R., Faria, D., Albuquerque, R., Paz, I., Artoni, S., Santos, A.L., Saviani, G., Araújo, C.M. 2012. Avaliação do desenvolvimento da discondroplasia tibial em frangos de corte submetidos à dieta com 25 hidroxicolecalciferol. Brazilian Journal of Veterinary Research and Animal Science, 49(2), 153-161. DOI: https://doi.org/10.11606/issn.23183659.v49i2p153-161.

Ross 308 AP (AP95). Objetivos de Desempenho. 2017. Ross An Aviagen Brand: http://pt.aviagen.com/assets/Tech_Center/BB_Foreign_Langu age_Docs/Portuguese/Ross308AP-PS-PO-PT-2017.pdf. (acessado em 18 de maio de 2020)

Ross. 2018. Manual de Manejo de frangos de corte. Ross An Aviagen Brand http://pt.aviagen.com/techcenter/download/1271/RossPSHandBook2018-PT.pdf. (acessado em 10 de fevereiro de 2020),

Sakomura, N.K., Rostagno, H.S. 2016. Métodos de pesquisa em nutrição de monogástricos. UNESP, Jaboticabal.

Seedor, J.G., Quartuccio, H.A., Thompson, D.D. 1991. The biophosphonate alendronate (MK-217) inhibit bone loss due to ovariectomy in rats. Journal of Boneand Mineral Research, 6(4), 339-346. DOI: https://doi.org/10.1002/jbmr.5650060405.

UBA. UNIÃO BRASILEIRA DE AVICULTURA. 2008. Protocolo de Bem-Estar para Frangos e Perus. https://avisite.com.br/legislacao/anexos/protocolo_de_bem_est ar_para_frangos_e_perus.pdf. (acessado em 05 de setembro de 2020)

Uzum, M.H , Toplu, H.D.O. 2013. Effects of stocking density and feed restriction on performance, carcass, meat quality characteristics and some stress parameters in broilers under heat stress. Revue de Médecine Vetérinaire, 164(12), 546-554. https://www.revmedvet.com/2013/RMV164_546_554.pdf. (acessado em 4 janeiro de 2021) 